\title{
DOES THE STRENGTHENING OF IPRS WIDEN THE GROWTH GAP?
}

\author{
Hwan-Joo SEO ${ }^{\mathrm{a}}$, Han Sung KIM ${ }^{\mathrm{b}}$, Young Soo $\mathrm{LEE}^{\mathrm{c}}$ \\ ${ }^{a}$ Division of Business Administration, Hanyang University, \\ 1271, Sa 1-dong, Sangrok-gu, Ansan, 426-791 Gyeonggi-do, South Korea \\ ${ }^{b}$ Department of Economics, Ajou University, \\ San 5, Woncheon-dong, Yeongtong-gu, 443-749 Suwon, South Korea \\ 'Department of Business Administration, Korea Aerospace University, \\ 200-1, Whajon-dong, Koyang, 412-791 Gyeonggi-do, South Korea
}

Received 04 March 2012; accepted 02 December 2012

\begin{abstract}
This article builds a model of cumulative growth in order to analyze the relationship between intellectual property rights (IPRs) and economic growth in 38 countries from 1980 to 2005. The analysis focuses on the impacts of IPRs on the growth gap between countries using a catch-up model and USPTO database. The empirical results show that the strengthening of IPRs has a positive impact on innovation in developed and developing countries in Asia, while we fail to find evidence in Latin America. Secondly, similar to assertions made by De Long and Summers (1991) and Dowrick and Nguyen (1989), investment in fixed capital plays a critical role in growth gap dynamics. What needs to be emphasized here is the cumulative causal relationship between investment and growth: investment in fixed capital improves productivity and encourages economic growth thereby triggering even more investment. This paper confirms that the strengthening of IPRs and investment in fixed capital contribute to the widening of the economic development gap for the 1980-2005 period.
\end{abstract}

Keywords: intellectual property rights, innovation, growth gap, cumulative causation.

JEL Classification: O34, O47.

\section{Introduction}

In the last several decades the nature of the world economy has changed dramatically. One of the most important changes involves the increasing importance of the production, diffusion and use of knowledge for improving the competitiveness of firms and overall economic performance (Schilling 2010). Technological change and scientific advance seem more rapid and more comprehensive than ever, and information and communication technologies have become a fact of economic life in the global economy.

Corresponding author Hwan-Joo Seo

E-mail: seohwan@hanyang.ac.kr 
However, country data on the number of patents, $R \& D$ expenditures and the number of researchers show that the level of knowledge capital and innovation capacity vary across countries and between industries, even among those with similar levels of economic development (Aghion, Griffith 2005; Aghion et al. 2009; Acemoglu, Akcigit 2012; Zeira 2011). It is feared that the knowledge gap will increase the growth gap and income inequality between developed and developing countries as the world economy moves toward a more global and knowledge-based economy.

If we consider the countries of origin of US utility patents, the top ten countries, which only comprise $14 \%$ of the world's population, account for nearly $94 \%$ of all of the patents taken out in the United States in the year 2000 (Sachs 2002). That is, the remaining 86\% of the world's population produces only $6 \%$ of US utility patents. For example, Sub-Saharan Africa, excluding the Republic of South Africa, has roughly 600 million people, but has only produced in total 1-3 patents in recent years. Using a simple indicator, Table 1 estimates the growth gap $\left(I_{t}\right)$ and knowledge gap $\left(P_{t}\right)$ with respect to the US in the year 2010. As shown in Table 1, the growth gap between Asian countries and the US, measured by the percentage of its per capita GDP to the US, is $23 \%$ of the US, while the knowledge gap, measured by the number of patents per 1,000 people, is only $16.1 \%$ of the US. For African countries, the growth gap and the knowledge gap are $5.0 \%$ and $0.09 \%$ of the US, for Eastern European countries, those are $25.1 \%$ and $1.1 \%$ and for South American countries, they are $20.1 \%$ and $0.19 \%$, respectively.

Table 1. Growth and knowledge gaps (2010)

\begin{tabular}{lcccc}
\hline & Asia & Africa & East Europe & South America \\
\hline Growth gap $\left(I_{2010}\right)$ & 0.230 & 0.050 & 0.251 & 0.201 \\
\hline Knowledge gap $\left(P_{2010}\right)$ & 0.161 & 0.0009 & 0.011 & 0.0019 \\
\hline
\end{tabular}

Source: US Patent and Trademark Office (USPTO) Database and World Bank World Development Indicators Online.

Notes:

1. $I_{t}=\frac{1}{n} \sum_{i=1}^{n} \frac{x_{i, t}}{x_{u s, t}}$ measures the growth gap between the US and other country groups, where $i$ denotes an individual country, $\boldsymbol{i}=1 \cdots \boldsymbol{n}, \boldsymbol{x}_{\boldsymbol{i}, t}$ is per capita income at time $\mathrm{t}$ for country $i$, and $\boldsymbol{x}_{\boldsymbol{u s}, \boldsymbol{t}}$ stands for per capita income for the US at time $t$. The growth gap narrows if $\boldsymbol{i}_{\boldsymbol{t}}$ is closer to 1 and it widens as $\boldsymbol{i}_{\boldsymbol{t}}$ approaches to 0 .

2. $P_{t}=\frac{1}{n} \sum_{i=1}^{n} \frac{y_{i, t}}{y_{u s, t}}$ estimates the knowledge gap between the US and other country groups, in which $i$ denotes an individual country, $\boldsymbol{i}=1 \cdots \boldsymbol{n}, \boldsymbol{y}_{\boldsymbol{i}, t}$ is the number of patents per 1000 person for country $i$ at time $t$, and $\boldsymbol{y}_{u s, t}$ measures for the US. If $\boldsymbol{P}_{\boldsymbol{t}}$ approaches 1, it means the knowledge gap narrows, while it widens as $\boldsymbol{P}_{\boldsymbol{t}}$ becomes closer to 0 .

3. Asian countries include Bangladesh, Myanmar, China, Hong Kong, India, Indonesia, Malaysia, Pakistan, Philippines, South Korea, Taiwan, Singapore, Sri Lanka, and Thailand; African countries include Ivory Coast, Egypt, Ethiopia, Ghana, Kenya, Morocco, Nigeria, Republic of South Africa, Tanzania, Zaire; South America countries are Argentina, Brazil, Chile, Columbia, Mexico, Peru, Venezuela; East European countries are Bulgaria, the Czech Republic, Yugoslavia, Poland, Hungary, Russia, Slovenia, Romania, Slovakia.

4. In order to analyze the knowledge gap, we select countries that have registered patents in USPTO and exclude developed countries like Japan from the sample. 
Figures 1-3 show that the knowledge gap between the US and other regions, excluding Asian countries, has continued to widen over the last 30 years. Even for Asian countries that performed relatively well compared to other regions, the number of patents per 1000 people is only $16.1 \%$ that for the US in 2010 (Fig. 1).

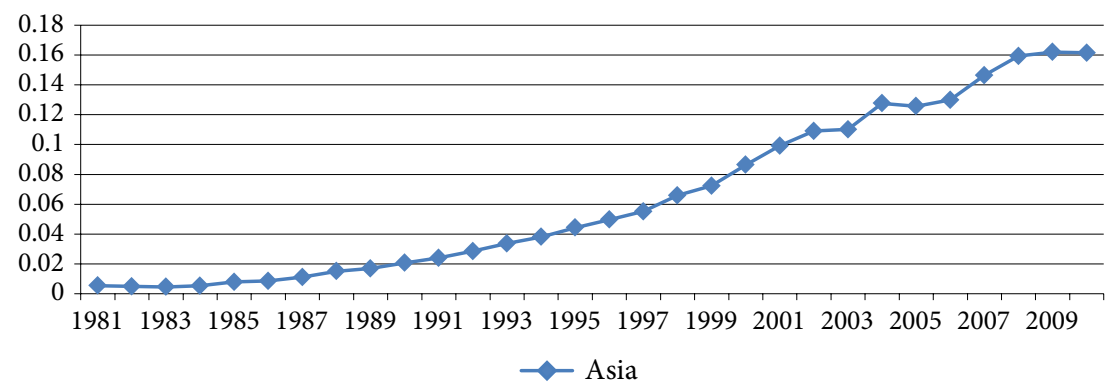

Fig. 1. Knowledge gap between Asian countries and the US Note: see Table 1.

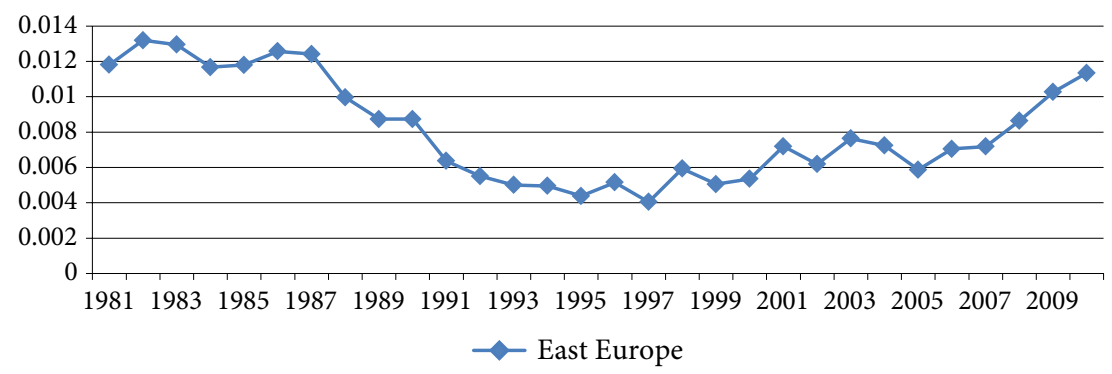

Fig. 2. Knowledge gap between East European countries and the US Note: see Table 1.

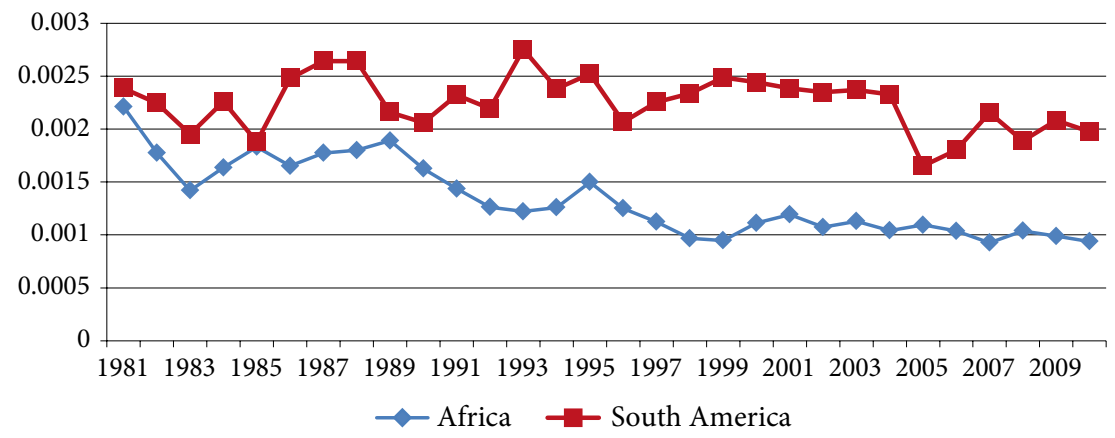

Fig. 3. Knowledge gap of African and South American countries with respect to the US Note: see Table 1. 
Strengthening intellectual property rights (IPRs) may be one of the most important institutional changes that have affected the knowledge gap between countries over the last two decades ${ }^{1}$. Initiated by the US in the late 1970s, these institutional reforms in the patent system proliferated worldwide through the Agreement on Trade-Related Aspects of Intellectual Property Rights (TRIPs), which has been introduced in 1994. It has strengthened the protection of patents, making it easier for patents to be enforced and granted for a longer time of patent's period. The reform has also extended patent rights to new subject areas, such as software, business models and biotechnology.

Nordhaus (1969), who initiated an economic analysis of the patent system, shows that by granting innovators temporary monopoly power, the protection of intellectual property enhances the incentives to allocate more to $R \& D$ and innovative activities, and further encourages technology transfer through a reduction in transaction costs related to intellectual property. However, recent studies have not yielded a clear conclusion on whether the strengthening of IPRs leads to more or less innovation (Kang, Seo 2005; Kortum, Lerner 1999; Hall, Ziedonis 2001; Sakakibara, Branstetter 2001; Maskus 2000; Kanwar, Evenson 2003; Gallini 2002; Arora et al. 2008; Boldrin, Levine 2009; Branstetter et al. 2011).

This paper aims to analyze the effects of strengthening of patent rights on the growth gap. Sample data is taken from 38 countries over the last 25 years and analysis is based on the Kaldorian cumulative growth model (Dixon, Thirlwall 1975; Boyer 1988; Amable 1993; Verspagen 1993). In the model, we present various cases where the strengthening of patent rights widens or narrows the growth gap between countries. IPRs influence the dynamics of the growth gap by way of encouraging innovation. Thus, a model of cumulative growth which takes into account IPRs can show various cases of both widening and narrowing of the growth gap. What makes this study different from previous ones (Park, Ginarte 1997; Gould, Gruben 1996) is that while Gould and Gruben construct a single equation to investigate the contribution of IPRs to economic growth, our model takes a more systematic approach, endogenizing the variables that Park and Ginarte (1997) and Gould and Gruben (1996) treat as exogenous. Also, using the United States Patent and Trademark Office (USPTO) database, we try to estimate the effects of strengthening patent rights on innovation and capital accumulation.

The rest of the article is organized as follows. Section 1 reviews the empirical evidence concerning impacts of IPRs on innovation. The empirical model will be introduced in Section 2. In Section 3, the results of the estimation will be explained. The final section concludes the paper.

\section{Previous studies}

Since the late 1970s, changes have taken place in regard to IPR-related regulations and policies. Researchers have focused on the effects of these changes on economic factors such as innovation, growth and technological diffusion. Empirical study into the strengthening of IPR has developed in two directions. First, observing the strengthening of IPR in the

\footnotetext{
1 Here and throughout the paper, we use IPRs and patent rights without distinction
} 
US (for example, creation of the Court of Appeals for the Federal Circuit (CAFC), the BayhDole Act and the expansion of the realm of patentability), researchers have investigated the relationship between the strengthening of IPR and technological innovation in developed economies, such as the US, Japan and the EU (Kortum, Lerner 1999; Cohen et al. 2000; Sakakibara, Branstetter 2001; Henderson et al. 1998; Mowery, Sampat 2001; Mowery et al. 2001; Mowery, Ziedonis 2002). As Jaffe (2000) points out, despite the significance of policy changes and wide availability of detailed data related to patenting, few robust conclusions can be drawn about the empirical consequences of changes in patent policy on technological innovation. Secondly, as international harmonization of IPR, such as through TRIP (Agreement on Trade-Related Aspects of Intellectual Property Rights), has progressed, researchers have analyzed how the effect of IPR strengthening on economic growth differs depending on the degree of economic development. In addition to the impact on economic growth, there are also approaches which have showed the effect of IPR protection on trade (Maskus, Penubarti 1995; Smith 1999, 2001) and FDI (Yang, Maskus 2001; Javorcik 2004).

Our concern in this study is to see how the relationship between IPR and economic growth differs depending on the level of economic development. In this section, we summarize previous studies which are related to our topic. We identify two different approaches for understanding the relationship between IPR and economic growth. One is to directly estimate the effect of IPR on output growth using growth regression (Gould, Gruben 1996; Thompson, Rushing 1996, 1999; Falvey et al. 2006). The other approach indirectly measures the impact of IPR on output growth by measuring its impact on innovation (using the number of patents as a proxy variable) and $\mathrm{R} \& \mathrm{D}$ (using R\&D activity as a proxy for innovation), which are important determinants of economic growth (Park, Ginarte 1997; Kanwar, Evenson 2003; Chen, Puttitanun 2005; Weinhold, Nair-Reichert 2008) ${ }^{2}$.

Gould and Gruben (1996) use growth regression in their estimation. Applying Rapp and Rozek's (1990) IPR measure, they test data for 95 countries during the 1960-1988 period and show how the effect of IPR protection on economic growth differed under closed and open economies. Their results reveal that IPR protection had a positive impact on growth. The positive impact of IPR protection was slightly stronger in open economies, but it was not robust. Thompson and Rushing (1996) run cross-section growth regression for 112 countries from 1970 to 1985 using Rapp and Rozek's (1990) IPR measure. Their empirical evidence, based on a switching regression model, points to a positive correlation between IPR protection and economic growth for those countries with an initial level of GDP per capita greater than or equal to $\$ 3,400$ (1980 dollars). Thompson and Rushing (1999) extend prior research (Thompson, Rushing 1996) using a simultaneous equation model covering the years from 1975 to 1990 for 55 countries, both developing and developed. The model is a system of three equations having average growth of GDP per capita, change in TFP (Total Factor productivity) and the Rapp and Rozek index as the three dependent variables. The estimation results once again show that IPR protection only had a positive and significant relationship on TFP (and thereby growth) in wealthier countries with an initial level of GDP per capita greater than $\$ 4,000$ in 1985 dollars. Falvey et al. (2006) investigate the role of IPR protection

\footnotetext{
2 Schneider (2005) and Kim et al. (2012) consider growth regression and innovation regression simultaneously.
} 
in an empirical growth model for a panel of 79 countries over the 1975-1995 period using threshold regression analysis. They show that the effect of IPR protection on growth depended upon the level of development (proxied by initial GDP per capita), but in a non-linear way. It was positively and significantly related to growth for low-and high-income countries, but not for middle-income countries.

On the other hand, Chen and Puttitanun (2005) run innovation regression to analyze the impact of IPR protection in developing countries. Looking at 64 developing countries during the period of 1975-2000, they use the Park and Ginarte (1997) index to measure the degree of IPR protection. In doing so, the number of patent applications filed at the US Patent Office by developing-country residents is used as the measure of innovation. Taking the IPR index, per capita GDP, tertiary enrollment ratio, economic freedom index and population as explanatory variables, the estimation uses the two-stage least square method. Their results show that IPR protection had a positive impact on technological innovation in developing countries and that this positive impact was stronger in countries at higher economic development levels. Weinhold and Nair-Reichert (2008) argue that income inequality influences innovation (and growth) via three channels: i) via its effect on institutional quality (and especially IPR); ii) via its effect on demand for standardized manufactures; and iii) via the supply of savvy market participants. They analyze these linkages using cross-section data covering the years from 1994 to 2000 for 53 countries, both developing and developed. As the measure of innovation, they use data on patents granted to residents and non-residents. In addition, they turn to data on foreign patents filed in the United States for checking robustness. The estimation results show that income inequality (via broader market participation by the population), and to some extent IPR protection, played a direct role in domestic innovation. However, non-resident patterns of patenting were influenced by relatively exogenous factors and degree of global integration rather than by the kinds of internal and institutional factors which spur domestic innovation.

Kanwar and Evenson (2003) and Park and Ginarte (1997) take the position that, unlike the results obtained from growth regression analysis and innovation regression analysis, IPR protection had an indirect influence on economic growth as it delivered positive impacts to R\&D investment and capital accumulation. Utilizing cross-country data, Kanwar and Evenson show that intellectual property protection had a strong positive effect on technological change (defined by R\&D investment expenditures). However, Park and Ginarte (1997) find that the institution of IPR does not appear to have had a direct impact on innovation in 60 countries during the 1960-1990 period. Instead, stronger IPR had the potential to improve economic growth by stimulating capital accumulation rather than by promoting innovative activities.

Lastly, Kim et al. (2012) show that IPR protection had differing impacts on economic growth depending on the economic development levels of countries. They compare the effects of two types of protection (patent protection and minor forms of IPRs (namely, utility models)) on economic growth and innovation according to the level of economic development. GMM estimation results show that patent protection was an important determinant of innovation and that patentable innovations contributed to economic growth in developed countries, but not in developing countries. Instead, in developing countries, the utility model is more conducive to innovation and growth. Thus, their analysis proposes that what matters 
to innovation and growth is not only the strength of intellectual property rights but also the application of the appropriate type of protection. Utility models were more effective than patent protection in countries where minor and incremental innovation was more important and pervasive than innovative research activities.

\section{Empirical model}

Following Dowrick and Nguyen (1989), Verspagen (1993) and Amable (1993), we define the growth gap between frontier and lagging countries as follows ${ }^{3}$ :

$$
G_{i}=\ln \frac{(Y / L)_{F}}{(Y / L)_{i}},
$$

where $F$ and $i$ represent a frontier and lagging country, respectively, and $Y_{F}, L_{F}, Y_{i}$ and $L_{i}$ represent output and employment for frontier $(F)$ and lagging $(i)$ country. Dividing output by the employment level, we derive labor productivity for the frontier country, $(Y / L)_{F}$, and for the lagging country, $(Y / L)_{i}$.

Suppose that output in lagging country $i$ follows the simple Cobb-Douglas production function form:

$$
Y_{i}=A_{i} L_{i}^{\alpha} K_{i}^{\beta}
$$

where $Y, A, L, K$ denote GDP, level of technology, employment and physical capital stock respectively. Equation (2) can also be expressed in terms of labor productivity, $(P R O)$ :

$$
\left(\frac{Y}{L}\right)_{i}=P R O_{i}=A_{i} L_{i}^{\alpha-1} K_{i}^{\beta} .
$$

The growth rate of labor productivity can be driven from the log difference of Equation $(3)^{5}$ :

$$
\operatorname{pro}_{i}=a_{i}+(\alpha-1) l_{i}+\beta k_{i},
$$

where: $\frac{P R \dot{O}}{P R O}=\operatorname{pro}, \frac{\dot{A}}{A}=a, \frac{\dot{L}}{L}=l, \frac{\dot{K}}{K}=k$.

Let us assume that the technological change takes a linear form, which can be written as following:

$$
a_{i}=a_{0}+\delta_{1} i p r_{i}+\delta_{2} t e r_{i}+\delta_{3} G_{i}
$$

Equation (5) implies that technological change for lagging countries is determined by the spillovers from other countries as well as domestic innovation effort. We assume that the amount of knowledge spillovers from abroad is proportional to the growth gap $\left(G_{i}\right)$, according to the catch up theory. Equation (8) is based on Romer's knowledge production

\footnotetext{
3 In this paper, growth means the growth due to improvement in productivity, not due to increase in input factors. Because of law of diminishing marginal product, the growth based on increase in inputs does not ensure the sustainable growth of a state.

4 The logarithmic specification is used to obtain the convenient property that for equal values of labor productivity levels, the productivity gap is zero.

5 Small letter represents the growth rate of capital letter in the model.
} 
function (1990) that the production of knowledge is determined by human capital and existing knowledge stock. The rhythm of technological change is also determined by the level of human capital represented by the tertiary enrollment ratio $\left(\text { ter }_{i}\right)^{6}$ and an institutional factor, in particular IPRs $\left(i p r_{i}\right)$. Patents and copyrights provide incentives to innovate because they enable innovators to exclude competition, thereby increasing the expected return on inventions (Nordhaus 1969). In addition, by providing incentives for inventors to disclose technical details about their inventions in patent publications, IPRs promote the diffusion of new knowledge. However, Helpman (1993), Bessen and Maskin (2009) and Bessen (2004) have a different view. They argue that broadening patent rights may have negative impacts on industries that depend on sequential and cumulative innovation. For example, while broadening of patent rights effectively protects original inventors, it increases the possible infringement on patents by firms that try to improve and further develop the original idea. This may encourage firms to adopt a passive attitude toward the innovation. As a result, the overall effect of broadening patents on innovation may be negative.

For the frontier country, in which no catch-up effect exists, the function of technological change can be written as follows:

$$
a_{F}=a_{0}+\delta_{1} i p r_{F}+\delta_{2} \text { ter }_{F} .
$$

Using Eqs (1)-(6), we derive the following cumulative growth model:

$$
\begin{gathered}
\operatorname{pro}_{i}=a_{i}+(\alpha-1) l_{i}+\beta k_{i} ; \\
a_{i}=a_{0}+\delta_{1} i p r_{i}+\delta_{2} \text { ter }_{i}+\delta_{3} G_{i} ; \\
k_{i}=k_{0}+\mu_{1} y_{i}+\mu_{2} r_{i} ; \\
\text { ter }_{i}=\text { ter }_{0}+\pi_{1} \sec _{i} ; \\
l_{i}=l_{0}+\gamma y_{i} ; \quad \quad<\text { Accounting identity }>.
\end{gathered}
$$

\footnotetext{
6 As the reviewer indicates, in general, R\&D expenditure is used as a key input of the knowledge production function. But we use human capital (regarding the tertiary enrollment ratio as a proxy variable) in Equation (8) for the following reasons. First of all, as Chen and Puttitanun (2005) and Weinhold and Nair-Reichert (2008) mention in their papers, reliable sources regarding R\&D are limited for developing countries, so using R\&D data constrains the number of countries which can be investigated, thus reducing the number of observations. On the other hand, by using human capital as a determining factor of the knowledge production function, we do not need to limit our analysis only to countries with reliable R\&D data since the World Bank provides systematic and reliable tertiary enrollment ratio data for developing countries, as well as developed countries. The estimation results that use "R\&D expenditure" in knowledge production function, instead of human capital proxy variable, are provided in Appendix VI. It includes 23 countries which we can obtain R\&D intensity (R\&D expenditure/GDP) data over 1980-2005 period; Australia, Austria, Belgium, Canada, Denmark, Finland, France, Greece, Ireland, Israel, Italy, South Korea, Japan, Mexico, Holland, New Zealand, Norway, Portugal, Spain, Sweden, Swiss, the UK, and the US.

7 We propose a technology production function based on Romer (1990) which combines technology-gap theory and institutional factors (IPR): $(\dot{A})_{i t}=a_{i t}=a_{0} i \operatorname{pr}_{i t}^{\delta_{1}} \operatorname{ter}_{i t}^{\delta_{2}} G_{i t}^{\delta_{3}} A_{i t}$ (8.1). By taking the first-order Taylor series expansion around zero of each variable from Equation (8.1), we can derive the following log-linear dynamic form equation: $\ln A_{i t}-\ln A_{i t-1}=\ln a_{0}+\delta_{1} \ln i p r_{i t}+\delta_{2} \operatorname{lnter} r_{i t}+\delta_{3} \ln G_{i t}$, where $a_{i t}=\left(\frac{A}{A}\right)_{i t} \cong \ln A_{i t}-\ln A_{i t-1}$ (8.2). Thus we can derive Equation (8) when we drop $t$ and $\ln$ form Equation (8.2).
} 
And one expects: $\mu_{1}>0, \mu_{2}<0, \pi_{1}>0, \gamma>0, \delta_{1}<>0, \delta_{2}>0, \delta_{3}>0, \alpha$ and $\beta>0$ where $y_{i}=\left(\frac{\dot{Y}}{Y}\right)_{i}$

Equation (9) shows that investments are influenced by the growth rate of demand $\left(y_{i}\right)$ according to the principle of acceleration (Dixon, Thirlwall 1975; Boyer 1988; Amable 1993). It is also a function of the real interest rate $\left(r_{i}\right)$. School enrollment in tertiary education $\left(\right.$ ter $\left._{i}\right)$, which shows the level of human resources in equation (10), can be presumed to be a function of secondary education $\left(\sec _{i}\right)$. Employment $\left(l_{i}\right)$ is presumed in Equation (11) to be influenced by the growth rate of demand $\left(y_{i}\right)$ addressed to the country. In Equation (12), the growth rate of the national income can be defined as the sum of the labor productivity growth rate and employment growth rate.

Using Eqs (7)-(12), we derive a reduced form. The growth rate of productivity is:

$$
\operatorname{pro}_{i}=A_{1}+B G_{i}
$$

where:

$$
\begin{aligned}
& A_{1}=\frac{(1-\gamma)}{(1-\gamma)-\gamma(\alpha-1)-\beta \mu_{1}}\left[\left(a_{0}+\frac{(\alpha-1)+\beta \mu_{1}}{(1-\gamma)} l_{0}+\beta k_{0}+\delta_{2} t e r_{0}\right)+\delta_{1} i p r_{i}+\beta \mu_{2} r_{i}+\delta_{2} \pi_{1} \sec _{i}\right] \\
& B=\frac{(1-\gamma) \delta_{3}}{(1-\gamma)-\gamma(\alpha-1)-\beta \mu_{1}} .
\end{aligned}
$$

Since $G_{i}=0$ for frontier country, the growth rate of productivity can be written as:

$$
\text { pro }_{F}=A_{2} \text {, }
$$

where:

$$
A_{2}=\frac{(1-\gamma)}{(1-\gamma)-\gamma(\alpha-1)-\beta \mu_{1}}\left[\left(a_{0}+\frac{(\alpha-1)+\beta \mu_{1}}{(1-\gamma)} l_{0}+\beta k_{0}+\delta_{2} t e r_{0}\right)+\delta_{1} i p r_{F}+\beta \mu_{2} r_{F}+\delta_{2} \pi_{1} \sec _{F}\right] \text {. }
$$

Using Equations (1), (13) and (14), we derive the following Equation (15):

$$
\dot{G}_{i}=\operatorname{pro}_{F}-\text { pro }_{i}=A_{2}-A_{1}-B G_{i} .
$$

So it can also be expressed with:

where:

$$
\dot{G}_{i}=A_{0}-B G_{i}
$$

$$
A_{0}=A_{2}-A_{1}=\left[\delta_{1}\left(i p r_{F}-i p r_{i}\right)+\beta \mu_{2}\left(r_{F}-r_{i}\right)+\delta_{2} \pi_{1}\left(\sec _{F}-\sec _{i}\right)\right] \frac{(1-\gamma)}{(1-\gamma)-\gamma(\alpha-1)-\beta \mu_{1}} \text {. }
$$

There are four possible cases depending on the signs of $A_{2}, A_{1}, B$ in Equation (15), and the time path of productivity gap, $G$, is as follows:

$$
G(t)=\left[G(0)-\frac{A_{0}}{B}\right] e^{-B t}+\frac{A_{0}}{B} .
$$

To check the various possibilities, let us consider the case that $\dot{G}_{i}=0$ in Equation (15). Then, it can be written as following:

$$
-B G_{i}=A_{1}-A_{2} .
$$


In Case 1 of Figure 4, there is an equilibrium gap of $G^{\star}=\frac{A_{0}}{B}>0$ regardless of the initial condition, so that lagging countries cannot completely catch up with the frontier country. Case 1 is similar to Nelson and Phelps's (1966) model, where the equilibrium gap was determined by the educational attainment of the lagging country. Diverging growth patterns are possible in Case 2, depending on the initial development level. In the case where the initial growth gap is $G(0)>\frac{A_{0}}{B}$, continuous broadening of the growth gap occurs, resulting in a vicious circle of underdevelopment. In contrast, if the initial growth gap is $G(0)<\frac{A_{0}}{B}$, a virtuous circle of growth and development is initiated, and the productivity level of the lagging country eventually converges to that of the frontier country.

Case 1. $A_{0}=A_{2}-A_{1}>0 \& B>0$

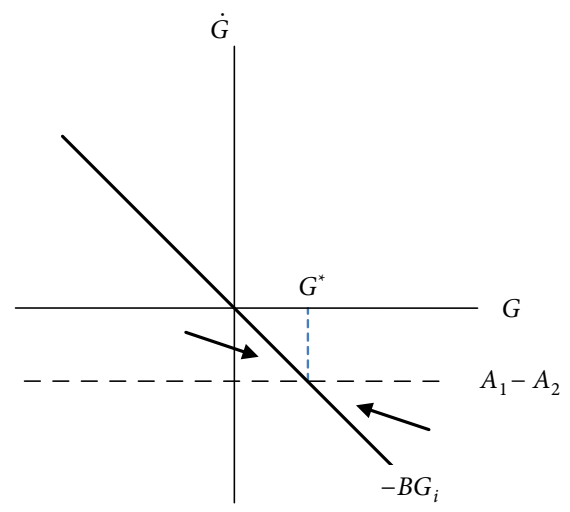

Case 3. $A_{0}=A_{2}-A_{1}>0 \& B<0$

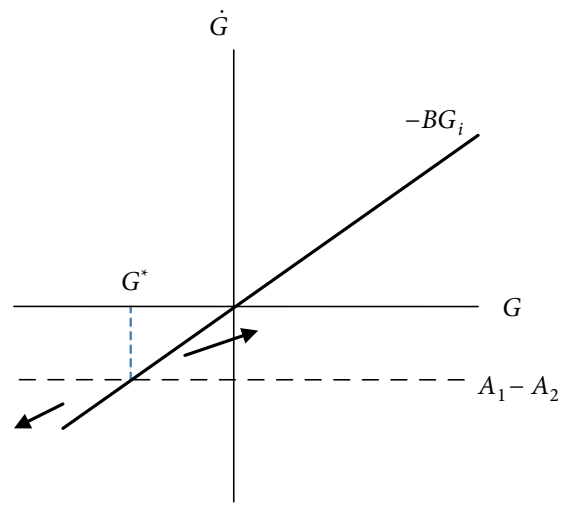

Case 2. $A_{0}=A_{2}-A_{1}<0 \& B<0$

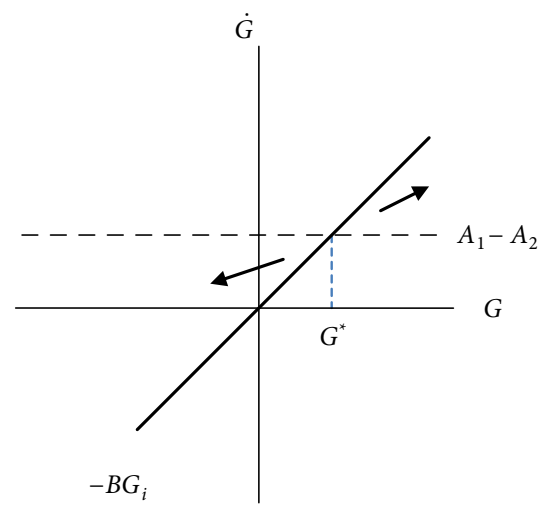

Case 4. $A_{0}=A_{2}-A_{1}<0 \& B>0$

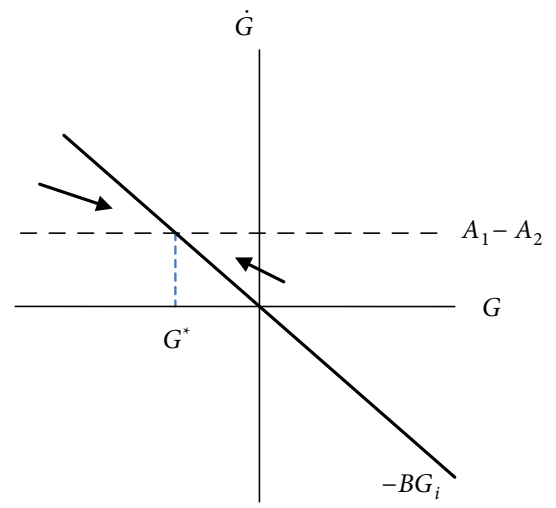

Fig. 4. Dynamics of the growth gap 
Case 3, parallel to Case 2, represents a different growth pattern centered on $\frac{A_{0}}{B}$. However, the case of the initial growth gap $G(0)<\frac{A_{0}}{B}$ shows $G(0)$ to be less than 0 , which violates the presumption. In other words, it is a case where the follower country's initial level of productivity was above the frontier country's. In the case that $G(0)>\frac{A_{0}}{B}$, the growth gap between the countries begins positive and keeps widening ${ }^{8}$. In Case 4 , the follower country catches up to the frontier country, regardless of initial development levels. The social capability of the lagging country allows for catch-up whatever the initial productivity level. $A_{1}$ in Equation (13) captures social capability, which is mentioned by Abramovitz (1986). That is, the level of human capital measured by the tertiary enrollment ratio, the institutional factors such as the degree of IPRs and/or the interest rate which shows the stability of macroeconomic environment are considered as social capability and countries with high social capability can catch-up developed countries.

\section{Estimation results}

We estimate the reduced Equation (16) to analyze whether lagging countries catch up with the frontier country. The test is conducted for 38 countries for 1980-2005 period ${ }^{9}$. In our test, frontier country $(F)$ is the US and the growth gap, $\dot{G}$ is the dependent variable that measures the difference in productivity growth between the US and individual country (Eq. (1)). Estimation (1) in Table 2 uses $G$ as an explanatory variable. It shows that larger the growth gap a country has, the faster it is in catching up. Such a result is equivalent to Case 1 in Figure 4, in which lagging countries fail to completely catch-up with the frontier country (the US), and converges to the equilibrium growth gap.

Table 2. Estimation of reduced equation

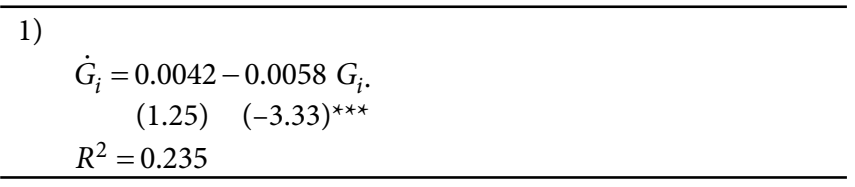

Note: 1 ) values in brackets are t-statistics; 2$)^{*},{ }^{* *},{ }^{* * *}$ represent statistical significance at $10 \%, 5 \%, 1 \%$, respectively.

The estimation results of the simultaneous-equations model for a cross-section sample of 38 countries during 1980-2005 are presented in Table (3) ${ }^{10}$. A list of the 38 countries and explanations for the variables adopted are shown in Appendix I and Appendix II, respectively. The selection of 38 countries is based on their availability of obtaining data regarding number

\footnotetext{
8 Since it is assumed that $\delta_{3}>0$ in Eq. (5), $B>0$. Therefore, Case 2 and Case 3 do not fit in the model described in this paper.

9 See Appendix III for summary statistics for the data used in the test.

${ }^{10}$ We take 1980 as a starting point since major countries, including the US, had converted their patent system from weak patent system to pro-patent regime in 1980s. Following Boyer (1988) who argues there was systematic change in world economy, we test for 1975-2005 period; however, there is no meaningful difference from 1980-2005 period.
} 
of patents, IPR index and other macroeconomic data needed for the analysis. For example, Eastern European countries are dropped out since the information regarding IPR index is not available for 1980-1994. We use the average growth rate of the number of patents filed to USPTO (pat) over the period 1980-2005 to approximate each country's innovative activity ${ }^{11}$. The country of origin of an application is based on the residence of the first inventor named. The IPR indices (ipr) are taken from Park (2008). The index incorporates the following five aspects of patent laws: extent of coverage, membership in international patent agreements, duration of protection, provisions for loss of protection, and enforcement mechanisms. The index is scored with a value ranging from 0 to 5 , with higher values of the index indicating stronger patent protection.

Growth rate of capital stock $(k)$ can be expressed as the product of the investment ratio $\left(\frac{I}{Y}\right)$ and the output-capital ratio $\left(\frac{Y}{K}\right) . I, K$ and $Y$ represent the investment, capital stock and GDP, respectively. If $\frac{Y}{K}$ is constant, then the growth rate of capital stock $(k)$ will be proportional to $\frac{I}{Y}$ which is the rate of investment. In the estimation, we use investment ratio $\left(\frac{I}{Y}\right)$ as a proxy in place of the rate of increase of capital stock.

Table 3 shows results for four estimations for 1980-2005. Model (1) estimates the impact of strengthening of IPRs on innovation without taking into account the development gap among countries. Models (2)-(4), on the other hand, consider the gap in economic development among the countries (Model (2)) and regional characteristics (Models (3) and (4)) in estimation. Model (2) employs two interactive terms; $i p r \cdot d u m_{a d v}$ variable which combines IPR index with developed country dummy and $i p r \cdot d u m_{d e v}$ variable which combines IPR index and developing country dummy. The interactive terms make it possible to estimate the impact of strengthening of IPRs on innovation, controlling the level of economic development. As Lall (2003) and Mansfield (1986) point out, if the impact of strengthening patent rights is varied according to the level of economic development, local technological capability and industrial structure, it is necessary to divide the samples into two groups based on GDP per capita ${ }^{12}$. Model (3) and Model (4) include interactive terms to control regional characteristics; Model (3) contains the interactive term of $i p r \cdot d u m_{\text {asia }}$, while Model (4) has ipr $\cdot d u m_{\text {lat }}$, where $d u m_{\text {asia }}$ and $d u m_{\text {lat }}$ are dummy variables for developing countries in Asia and Latin America, respectively ${ }^{13}$.

In the first equation of Model (1), which tests the general impact of IPRs on innovation, our results show that the investment in fixed capital and the technological change represented by the number of patents have been the factors determining economic growth for the last 25 years. Like in De Long and Summers (1991) and Dowrick and Nguyen (1989), investment in fixed

\footnotetext{
11 The results are similar when we use the average growth rate of patent stock instead of that of number of patents.

12 There are 19 developed countries in our analysis; Australia, Austria, Belgium, Canada, Denmark, Finland, France, Iceland, Israel, Italy, Japan, Holland, New Zealand, Norway, Singapore, Sweden, Swiss, the UK, and the US. Also, 19 countries are categorized as developing countries, including Argentina, Chile, China, Colombia, Egypt, Greece, India, Indonesia, Korea (South), Malaysia, Mexico, South Africa, Spain, Thailand, Venezuela, Brazil, the Philippine, Portugal and Turkey. We regard countries as developed if their GDP per capita is more than $\$ 15,000$ and less developed if less than $\$ 15,000$ in 2000 .

13 Developing countries in Latin America includes Argentina, Brazil, Chile, Colombia, Mexico and Venezuela. China, India, Indonesia, Korea, Malaysia, Philippines, Thailand are included in developing countries in Asia.
} 
Table 3. Estimation of the simultaneous-equations model

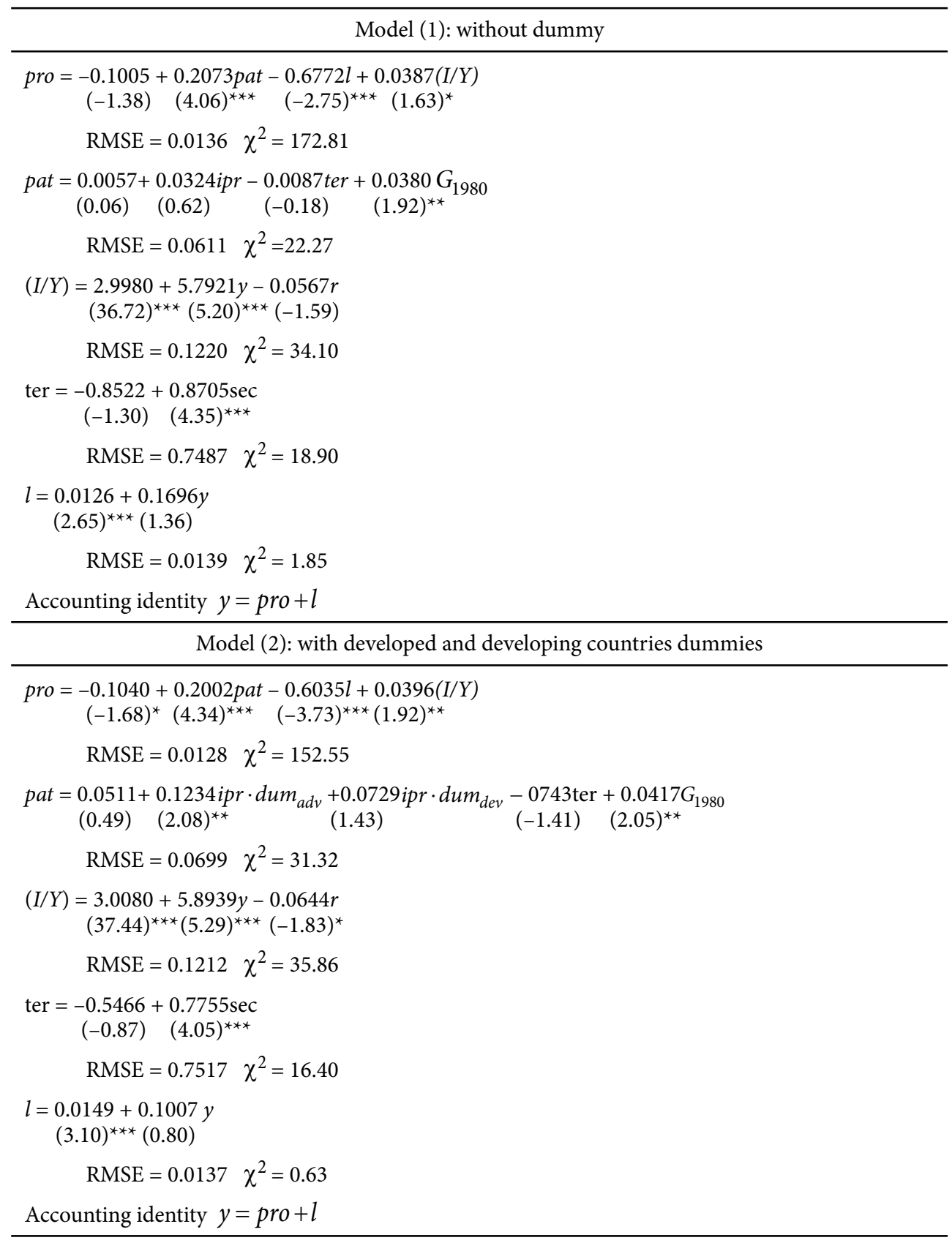


Continued Table 3

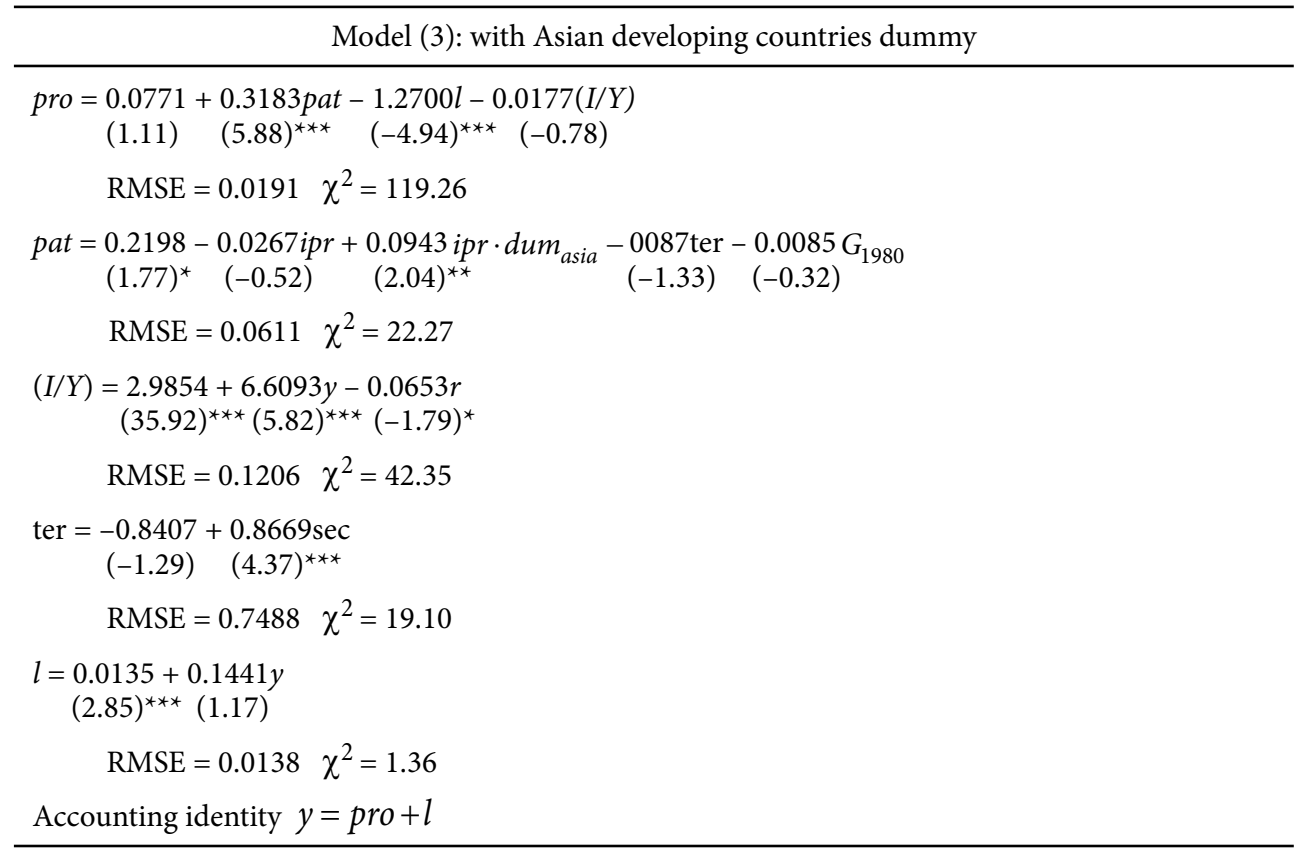

Model (4): with Latin American developing countries dummy

$$
\begin{aligned}
& \text { pro }=-0.1536+0.1503 \text { pat }-0.0590 l+0.0536(I / Y) \\
& (-2.42)^{* *}(3.36)^{* * *}(-0.36) \quad(2.56)^{* * *} \\
& \text { RMSE }=0.0101 \chi^{2}=161.75 \\
& \text { pat }=0.0209+0.0329 \mathrm{ipr}-0.0294 \mathrm{ipr} \cdot \mathrm{dum}_{\text {lat }}-0111 \mathrm{ter}+0.0329 \mathrm{G}_{1980} \\
& \begin{array}{llll}
(0.22) \quad(0.65) \quad(-0.85) \quad(-0.25) \quad(1.76)^{*} & 0
\end{array} \\
& \mathrm{RMSE}=0.0589 \chi^{2}=20.23 \\
& (I / Y)=3.0276+5.8305 y-0.0743 r \\
& (39.56)^{* * *}(5.24)^{* * *}(-2.31)^{* *} \\
& \text { RMSE }=0.1203 \quad \chi^{2}=39.00 \\
& \text { ter }=-0.9333+0.8957 \mathrm{sec} \\
& (-1.42) \quad(4.46)^{\star * *} \\
& \text { RMSE }=0.7487 \quad \chi^{2}=19.92 \\
& l=0.0139+0.1316 y \\
& (2.87)^{* * *}(1.04) \\
& \text { RMSE }=0.0137 \quad \chi^{2}=1.07
\end{aligned}
$$

Accounting identity $y=$ pro $+l$

Note: 1) Method of estimation: 3SLS (three-stage least squares estimation method); 2) values in brackets are t-statistics; 3$)^{*},{ }^{* *},{ }^{* *}$ represent statistical significance at $10 \%, 5 \%, 1 \%$, respectively; 4) Exogenous variables are ipr, $G, y, r$, and sec. 
capital has a positive impact on narrowing the growth gap among countries via the amelioration of productivity. The growth rate of the number of patents in the US, which is the proxy variable for technical innovation, turns out to have a positive impact on productivity growth; productivity is increased by $0.20 \%$ for $1 \%$ incline in the growth of the number of patents. The growth rate of employment $(l)$ shows statistically significant coefficient of -0.677 . Since $\alpha-1=-0.677$ from Equation (4), it implies that $\alpha=0.323$.

The second equation of Model (1) showed that the impact of strengthening patent rights on the innovation was not statistically significant, which is consistent with Park and Ginarte (1997), Kortum and Lerner (1999), Hall and Ziedonis (2001) and Sakakibara and Branstetter (2001). They cast doubt on the effectiveness of patent systems in encouraging innovation. The result implies that unlike theoretical expectations, the economic effects of patents on innovative activities are absent in this estimation. The catch-up effect in the second equation turns out to be positive and statistically significant. This implies that lagging countries profit from the spillover effect propagated by frontier countries as suggested by Verspagen (1993) and Amable (1993). Tertiary enrollment ratio which captures the degree of human capital, however, fails to be statistically significant. This is coincident with previous estimations (Kanwar, Evenson 2003; Schneider 2005; Chen, Puttianun 2005). It may be due to difficulty of finding an adequate variable which reflects the degree of human capital (for example, which variable is better for measuring human capital between enrollment ratio and literacy rate? If the enrollment ratio is the one, what should we choose between secondary and tertiary enrollment ratio?) and heterogeneity problem arising from cross-country analysis. On the other hand, tertiary enrollment ratio has a positive relation with the secondary enrollment ratio. Lastly, average annual GDP growth rate fail to have statistically-significant relation with average annual growth rate of employment in Model (1). In the third equation, investment in physical capital is determined by GDP growth and real interest rate. As expected, the results show negative signs for the real interest rate and positive signs for GDP growth. Since the interaction between productivity, investment and GDP growth form a cumulative mechanism in the model, high GDP growth accelerates the investment in capital, which improves productivity and further encourages GDP growth (i.e. virtuous circle of growth). On the other hand, the opposite scenario (i.e. vicious circle of growth) is equally possible; low GDP growth cause low investment and low productivity growth, leading the economy to lower rates of GDP growth.

While Model (1) allows us to see the relation between IPRs and innovation in general, it has limitation that it has not taken into account the economic development gap among the countries and/or regional characteristics. As Lall (2003), Mansfield (1986) and Schneider (2005) pointed out, countries have different innovation policies due to their differences in industrial structure. For developed countries that have high technology based industrial structure, the strengthening of IPR protection could work effectively. On the other hand, IPR protection would not work property for developing countries whose production is based on traditional industry where reverse-engineering and imitation are important (Masfield 1986; Lall 2003). Also, since developing country's innovation is more focused on imitation and adaptation, the impact of the strengthening of IPRs on innovation would not be as effective as in case of developed countries (Thompson, Rushing 1996, 1999). Sound economic environment in protecting IPRs, such as macroeconomic and political stability, 
economic openness and human capital, would be necessary condition for the strengthening of IPRs to have an impact on innovation (Kang, Seo 2005). To reflect such view, Model (2) estimate developed and developing countries separately and Models (3) and (4) take into account regional characteristics. The difference between Model (1) and Models (2)-(4) lies in the second equation which measures the effect of IPRs on innovation. Model (2) includes interactive terms, $i p r \cdot d u m_{a d v}$ and $i p r \cdot d u m_{d e v}$, which combines IPR index with developed and developing country dummy, respectively. The result shows that $i p r \cdot d u m_{a d v}$ capturing IPR effect of developed countries have positive value and statistically significant, while that for developing country, $i p r \cdot d u m_{d e v}$, also shows a positive relation but is not statistically significant. Similar to Schneider (2005), Thomson and Rushing (1996, 1999) and Lall (2003), it shows that the strengthening of IPR has not uniform, but has different outcome depending on its economic development. It implies that the strengthening of IPRs can bring positive impact on innovation only if the country passes a certain level of economic development. Our result also supports the previous research which emphasizes the economic development gap and the strengthening of IPRs can hinder developing countries' innovation because their innovative is incremental and cumulative, not radical innovation (Bessen, Maskin 2009).

Models (3) and (4) control regional characteristic; Model (3) includes developing countries in Asia and Model (4) contains developing countries in Latin America ${ }^{14}$. Models (3) and (4) include regional dummies, $i p r \cdot d u m_{\text {asia }}$ and $i p r \cdot d u m_{\text {lat }}$, in the second equation, respectively and estimate the impact of strengthening of IPRs on innovation. Like in Model (1), both Models (3) and (4) fail to be statistically significant for IPR index (ipr). However, a regional interactive dummy for Asian developing countries ( $i p r \cdot d u m_{\text {asia }}$ ) in Model (3) show a positive relation with innovation and statistically significant. It can be interpreted that the strengthening of IPRs in Asian developing countries has positive impact on innovation, even though the coefficient (0.0943) is smaller than in the case of developed countries (0.1234). On the other hand, we fail to find evidence that the strengthening of IPRs boost technological innovation in Latin America ${ }^{15,16 .}$

${ }^{14}$ Due to the limited availability of data for African countries, we exclude the estimation for African developing countries.

15 In order to analyze the impact of TRIPs, we divide our sample period into 1980-1990 and 1995-2005. The results are summarized in Appendix IV. It turns out that the strengthening of IPRs fails to be statistically significant during 1980-1990, while it has statistically significant positive coefficient during 1995-2005. This implies that the strengthening of IPRs through TRIPs has positive impact on innovation.

${ }^{16}$ As the reviewer points out, using USPTO data has advantages and disadvantages. It can be considered a positive aspect of using USPTO data that all patents are subject to the same regulations and level of scrutiny, so individual country effects are not a factor (Weinhold, Nair-Reichert 2008). However, there may be countries relatively less interested in patent registration at the USPTO if the US is not a major trading partner or FDI sourcing country. In this case, using USPTO data can underestimate innovative capacity. Considering these issues, we perform verification of robustness using data on patent applications by residents and data on patents granted to residents. When data on patents granted to residents is used, the estimation result fails to be statistically significant. On the other hand, the estimation using data on patent applications by residents shows the following results, which are similar to ours that uses foreign patents filed in the US (Appendix V). (i) In Model (1), in which differences in economic development are not considered, it fails to prove that IPR protection accelerates technological innovation; (ii) When differences in economic development are taken into account, the results show that IPR protection boosts technological innovation in developed countries, but this is not the case for developing countries; (iii) When the model considers regional differences among developing countries, the results confirm that IPR protection has a positive impact on technological innovation in Asia, but we fail to prove it for developing economies in South America. According to the robustness check using data on patent applications by residents, we can find similarity and consistency between the two estimations. 


\section{Conclusions}

Even if no clear agreement is drawn on whether reinforcement of patent rights is an effective policy tool to encourage innovation and knowledge diffusion, over the past two decades, most countries encouraged by the success of the US economy in patenting activity have moved their patent systems toward pro-patent regimes. At the global level, IPRs are included in international negotiations and TRIPs provides a standard for harmonizing patent laws across countries. The proponents of strong patent rights systems insist that the strengthening of patent rights may stimulate $\mathrm{R} \& \mathrm{D}$ and innovation, facilitate technology transfer and accelerate commercialization. Regarding the growth gap among countries, they claim that it helps to narrow the knowledge gap between frontier and lagging countries by boosting official technology diffusion like foreign direct investment and licensing even though reinforcing patent rights can have a negative impact on unofficial technology diffusion such as imitation and reverse engineering.

This paper empirically estimates the impact that protecting IPRs has had on growth in 38 countries for the last 25 years. Our estimates exhibit the following results. First, using the number of patents filed to the USPTO as a proxy variable for innovation, this paper finds that technological change is an important factor for explaining the growth gap among countries. Second, similar to assertions made by Delong and Summers (1991) and Dowrick and Nguyen (1989), investment in fixed capital plays a critical role in growth gap dynamics. What needs to be emphasized here is the cumulative causal relationship between investment and growth: investment in fixed capital improves productivity and encourages economic growth thereby triggering even more investment. We show that this relationship enlarged the disparity among countries during the last 25 years. Third, the result is consistent with Lall (2003), Mansfield (1986), Thomson and Rushing (1996, 1999) and Schneider (2005), in the sense that the strengthening of IPRs has not uniform, but diverse outcomes depending on its economic development. That is, because technological innovation in developing countries is more of imitation and adaption of existing technology and is incremental and cumulative innovation, the strengthening of IPRs can have negative effect, which hinders their innovative process. However, there exists differences regionally; the strengthening of IPRs in Asian developing countries has positive impact on innovation, while we fail to find same result in Latin America. Fourthly, from the facts that innovation and productivity have positively correlated and the strengthening of IPRs boosts innovation in developed countries and developing countries in Asia, we can conclude that the strengthening of IPRs contributes to the widening the growth gap between developed countries (and developing countries in Asia) and other developing countries during 1980-2005. Lastly, we find that the development paths of countries for the last 25 years are not converging in a single direction but actively varied. The diversity of growth paths is related not only to investment in physical capital, but also to technological change and social capability. Therefore, each country might create a favorable macroeconomic environment for investment via maintaining sound financial institutions.

In our research, we find that there exist different results of strengthening of IPRs on innovation between Asian and Latin American developing countries. We focus on if there is any regional difference and do not concentrate on what brings such result. It may be due to the difference in industrial structure, innovation policy, and/or economic environment and can be affected by many other possible factors. This will be an interesting issue and we leave this for future research. 


\section{References}

Abramovitz, M. 1986. Catching up, forging ahead and falling behind, Journal of Economic History 46(2): 385-406. http://dx.doi.org/10.1017/S0022050700046209

Acemoglu, D.; Akcigit, U. 2012. Intellectual property rights policy, competition and innovation, Journal of the European Economic Association 10(1): 1-42. http://dx.doi.org/10.1111/j.1542-4774.2011.01053.x

Aghion, R.; Blundell, R.; Griffith, R.; Howitt, P.; Prantl, S. 2009. The effects of entry on incumbent innovation and productivity, Review of Economics and Statistics 91(1): 20-32. http://dx.doi.org/10.1162/rest.91.1.20

Aghion, P.; Griffith, R. 2005. Competition and growth: reconciling theory and evidence. Cambridge, Mass.: MIT Press. 128 p.

Amable, B. 1993. Catch-up and convergence: a model of cumulative growth, International Review of Applied Economics 7(1): 1-25. http://dx.doi.org/10.1080/758528250

Arora, A.; Ceccagnoli, M.; Cohen, W. M. 2008. R\&D and patent premium, International Journal of Industrial Organization 26(5): 1153-1179. http://dx.doi.org/10.1016/j.ijindorg.2007.11.004

Bessen, J. 2004. Holdup and licensing of cumulative innovations with private information, Economic Letters 82(3): 321-326. http://dx.doi.org/10.1016/j.econlet.2003.08.004

Bessen, J.; Maskin, E. 2009. Sequential innovation, patents and imitation, RAND Journal of Economics 40(4): 611-635. http://dx.doi.org/10.1111/j.1756-2171.2009.00081.x

Boldrin, M.; Levine, D. K. 2009. Market size and intellectual property protection, International Economic Review 50(3): 855-881. http://dx.doi.org/10.1111/j.1468-2354.2009.00551.x

Boyer, R. 1988. Formalizing growth regimes, in G. Dosi, C. Freeman, R. Nelson, G. Silverberg, L. Soete, (Eds.). Technical change and economic theory. London: Pinter Publishers, 608-630.

Branstetter, L.; Fisman, R.; Foley, C. F.; Saggi, K. 2011. Does intellectual property rights reform supr industrial development?, Journal of International Economics 83(1): 27-36. http://dx.doi.org/10.1016/j.jinteco.2010.09.001

Chen, Y.; Puttitanun, T. 2005. Intellectual property rights and innovation in developing countries, Journal of Development Economics 78(2): 474-493. http://dx.doi.org/10.1016/j.jdeveco.2004.11.005

Cohen, W.; Nelson, R.; Walsh, J. P. 2000. Protecting their intellectual assets: appropriability conditions and why U.S. manufacturing firms patent (or not), NBER Working Paper, No. 7522, Washington, D.C.: National Bureau of Economic Research.

De Long, B.; Summers, L. H. 1991. Equipment investment and economic growth, Quarterly Journal of Economics 106(2): 445-502. http://dx.doi.org/10.2307/2937944

Dixon, R. J.; Thirlwall, A. P. 1975. A model of regional growth-rate differences on Kaldorian lines, Oxford Economic Papers 27: 201-214.

Dowrick, S.; Nguyen, D. 1989. OECD comparative economic growth 1950-1985: catch-up and convergence, American Economic Review 79: 1010-1030.

Falvey, R.; Foster, N.; Greenaway, D. 2006. Intellectual property rights and economic growth, Review of Development Economics 10(4): 700-719. http://dx.doi.org/10.1111/j.1467-9361.2006.00343.x

Gallini, N. T. 2002. The economics of patents: lessons from recent U.S. reform, Journal of Economic Perspectives 16(2): 131-154. http://dx.doi.org/10.1257/0895330027292

Gould, D. M.; Gruben, W. C. 1996. The role of intellectual rights in economic growth, Journal of Development Economics 48(2): 323-350. http://dx.doi.org/10.1016/0304-3878(95)00039-9

Hall, B. H.; Ziedonis, R. H. 2001. The patent paradox revisited: an empirical study of patenting in the U.S. semiconductor 1975-1995, Advances in Strategic Management 26: 341-379.

http://dx.doi.org/10.1108/S0742-3322(2009)0000026035 
Helpaman, E. 1993. Innovation, imitation and intellectual property rights, Econometrica 61(6): 1247-1280. http://dx.doi.org/10.2307/2951642

Henderson, R.; Jaffe, A. B.; Trajtenberg, M. 1998. Universities as a source of commercial technology: a detailed analysis of university patenting, 1965-1988, Review of Economics and Statistics 80(1): 127-199. http://dx.doi.org/10.1162/003465398557221

Jaffe, A. B. 2000. The U.S. patent system in transition: policy innovation and the innovation process, Research Policy 29: 531-557.

Javorcik, B. S. 2004. The composition of foreign direct investment and protection of intellectual property rights: evidence from transition economics, European Economic Review 48(1): 39-62.

http://dx.doi.org/10.1016/S0014-2921(02)00257-X

Kang, S. J.; Seo, H. J. 2005. Does stronger intellectual property rights induce more patents without complementary environments?, in B. van Pottelsberghe, C. Peeters, (Eds.). Economic and management perspectives on intellectual property rights. New York: Palgrave McMillian.

Kanwar, S.; Evenson, R. 2003. Does intellectual property protection spur technological change?, Oxford Economic Papers 55(2): 235-264. http://dx.doi.org/10.1093/oep/55.2.235

Kim, Y.; Lee, K.; Park, W.; Choo, K. 2012. Appropriate intellectual property protection and economic growth in countries at different levels of development, Research Policy 41(2): 358-375. http://dx.doi.org/10.1016/j.respol.2011.09.003

Kortum, S.; Lerner, J. 1999. What is behind the recent surge in patenting?, Research Policy 28(1): 1-22. http://dx.doi.org/10.1016/S0048-7333(98)00082-1

Lall, S. 2003. Indicators of the relative importance of IPRs in developing countries, Research Policy 32(9): 1657-1680. http://dx.doi.org/10.1016/S0048-7333(03)00046-5

Mansfield, E. 1986. Patents and innovation: an empirical study, Management 32: 173-181.

Maskus, K. E. 2000. Intellectual property rights in the global economy. Institute for International Economics, Washington, D.C.

Maskus, K. E.; Penubarti, M. 1995. How trade-related are intellectual property rights?, Journal of International Economics 39(3-4): 227-248. http://dx.doi.org/10.1016/0022-1996(95)01377-8

Mowery, D. C.; Nelson, R.; Sampat, B.; Ziedonis, A. 2001. The growth of patenting and licensing by U.S. universities: an assessment of the effects of the Bayh-Dole act of 1980, Research Policy 30(1): 99-119. http://dx.doi.org/10.1016/S0048-7333(99)00100-6

Mowery, D. C.; Sampat, B. N. 2001. University patents and patent policy debates in the USA, 1925-1980, Industrial and Corporate Change 10(3): 781-814. http://dx.doi.org/10.1093/icc/10.3.781

Mowery, D. C.; Ziedonis, A. 2002. Academic patent quality and quantity before and after the Bayh-Dole act in the United States, Research Policy 31(3):399-418. http://dx.doi.org/10.1016/S0048-7333(01)00116-0

Nelson, R.; Phelps, E. S. 1966. Investment in humans, technological diffusion, and economic growth, American Economic Review 61: 69-75.

Nordhaus, W. D. 1969. Invention, growth, and welfare: a theoretical treatment of technological change. Cambridge, MA: MIT Press. 168 p.

Park, W. G. 2008. International patent protection: 1960-2005, Research Policy 37: 761-766.

Park, W. G.; Ginarte, J. C. 1997. Intellectual property and economic growth, Contemporary Economic Policy 15(3): 51-61. http://dx.doi.org/10.1111/j.1465-7287.1997.tb00477.x

Rapp, W.; Rozek, R. 1990. Benefits and costs of intellectual property protection in developing countries, Journal of World Trade 24: 74-102.

Romer, P. 2000. Endogenous technological change, Journal of Political Economy 98(5): S71-S102. http://dx.doi.org/10.1086/261725 
Sachs, J. 2003. The global innovation divide, in A. Jaffe, J. Lerner, S. Stern (Eds.). Innovation policy and the economy. Vol. 3. Cambridge: MIT Press, 121-143.

Sakakibara, M.; Branstetter L. 2001. Do stronger patents induce more innovation? Evidence from the 1988 Japanese patent law reforms, RAND Journal of Economics 32: 77-100.

Schneider, P. H. 2005. International trade, economic growth and intellectual property rights: a panel data study of developed and developing countries, Journal of Development Economics 78(2): 529-547. http://dx.doi.org/10.1016/j.jdeveco.2004.09.001

Schilling, M. A. 2010. Strategic management of technological innovation. New York: McGraw-Hill. 313 p.

Smith, P. J. 1999. Are weak patent rights a barrier ti US exportd?, Journal of International Economics 48(1): 151-177. http://dx.doi.org/10.1016/S0022-1996(98)00013-0

Smith, P. J. 2001. How do foreign patent right affect US exports, affiliate sales, and licenses, Journal of International Economics 55(2): 411-439. http://dx.doi.org/10.1016/S0022-1996(01)00086-1

Thomson, M. A.; Rushing, F. W. 1996. An empirical analysis of the impact of patent protection on economic growth, Journal of Economic Development 21: 61-74.

Thomson, M. A.; Rushing, F. W. 1999. An empirical analysis of the impact of patent protection on economic growth: an extension, Journal of Economic Development 24: 67-76.

Verspagen, B. 1993. Uneven growth between interdependent economies. Amsterdam: Avebury. 296 p.

Weinhold, D.; Nair-Reichert, U. 2008. Innovation, inequality and intellectual property rights, World Development 37(5): 889-901. http://dx.doi.org/10.1016/j.worlddev.2008.09.013

Yang, G.; Maskus, K. E. 2001. Intellectual property rights, licensing, and innovation in an endogenous product-cycle model, Journal of International Economics 53(1): 169-187. http://dx.doi.org/10.1016/S0022-1996(00)00062-3

Zeira, J. 2011. Innovations, patent races and endogeneous growth, Journal of Economic Growth 16(2): 135-156. http://dx.doi.org/10.1007/s10887-011-9066-1 


\section{APPENDIX I}

\section{List of the 38 countries}

Argentina, Australia, Austria, Brazil, Belgium, Canada, Chile, China, Columbia, Denmark, Egypt, Finland, France, Greece, India, Indonesia, Ireland, Israel, Italy, Japan, Korea, Malaysia, Mexico, Netherlands, New Zealand, Norway, Philippines, Portugal, Republic of South Africa, Singapore, Spain, Sweden, Swiss, Thailand, Turkey, United Kingdom, United States of America, Venezuela.

\section{APPENDIX II}

List of variables

pro: Average annual growth rate of GDP per worker between 1980-2005

Data: World Bank World Development Indicators Online, ILO Database

$G$ : Growth gap in 1980 measured as a percentage of USA level of labor productivity

Data: World Bank World Development Indicators Online, ILO Database

pat: Average growth rate of the number of patents filed to USPTO for 1980-2005

Data: USPTO database

ter: Tertiary enrollment ratio in 1980

Data: World Bank World Development Indicators Online

sec: Secondary enrollment ratio in 1980

Data: World Bank World Development Indicators Online

ipr: Intellectual Property Rights Index Values (Average 1980-2005)

Data: Park (2008)

$l:$ Average annual growth rate of employment between 1980-2005

Data: ILO Database

I/Y: Average ratio of investment on GDP between 1980-2005

Data: World Bank World Development Indicators Online

$y$ : Average annual GDP growth rate between 1980-2005 (2000 US dollars)

Data: World Bank World Development Indicators Online

$r$ : Average real interest rate between 1980-2005

Data: World Bank World Development Indicators Online

\section{APPENDIX III}

Basic statistics

\begin{tabular}{ccccc}
\hline Variables & Average & $\begin{array}{c}\text { Standard } \\
\text { deviation }\end{array}$ & Minimum & Maximum \\
\hline pro & 0.022 & 0.016 & -0.009 & 0.081 \\
$I / Y$ & 3.090 & 0.177 & 2.857 & 3.540 \\
pat & 0.074 & 0.073 & -0.026 & 0.310 \\
$l$ & 0.019 & 0.015 & 0.001 & 0.069 \\
$i p r$ & 1.055 & 0.399 & -0.410 & 1.552 \\
sec & 0.088 & 0.534 & 0 & 4.141 \\
$r$ & 1.759 & 0.536 & 1.125 & 3.964 \\
$t e r$ & 1.930 & 0.918 & -0.223 & 3.621 \\
\hline
\end{tabular}

Note: $\log$ are applied to all variables. 


\section{APPENDIX IV}

Impact of TRIPs

\begin{tabular}{|c|c|}
\hline $1980-1990$ & 1995-2005 \\
\hline $\begin{aligned} \text { pro }= & -0.1747+0.0292 p a t+0.8479 l+0.0571(I / Y) \\
& (-3.91)^{\star * *}(1.52) \quad(3.23)^{\star * *}(3.88)^{* * *}\end{aligned}$ & $\begin{aligned} \text { pro }= & -0.30075+0.0123 \text { pat }-0.2673 l+0.1074(I / Y) \\
& (-3.76)^{* * *}(0.26) \quad(-1.19) \quad(4.13)^{* * *}\end{aligned}$ \\
\hline $\mathrm{RMSE}=0.0157 \quad \chi^{2}=46.90$ & $\mathrm{RMSE}=0.0186 \quad \chi^{2}=50.09$ \\
\hline 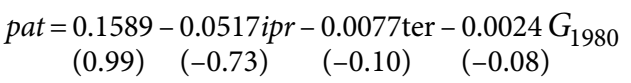 & $\begin{aligned} \text { pat }= & 1.1631+0.7548 \mathrm{ipr}-0.7619 \text { ter }-0.0904 G_{1980} \\
& (2.71)^{\star * *}(3.65)^{* * *}(-3.89)^{\star * *}(-1.59)\end{aligned}$ \\
\hline $\mathrm{RMSE}=0.1463 \chi^{2}=2.24$ & $\mathrm{RMSE}=0.3473 \quad \chi^{2}=44.09$ \\
\hline $\begin{aligned}(I / Y)= & 3.2277+5.7789 y-0.1646 r \\
& (39.88)^{\star * *}(6.08)^{\star * *}(-4.29)^{\star * *}\end{aligned}$ & $\begin{aligned}(I / Y)= & 2.8636+6.6369 y-0.0185 r \\
& (42.37)^{\star * *}(4.60)^{\star * *}(-0.71)\end{aligned}$ \\
\hline $\mathrm{RMSE}=0.1176 \quad \chi^{2}=60.90$ & $\mathrm{RMSE}=0.1534 \quad \chi^{2}=21.29$ \\
\hline $\begin{aligned} \text { ter }= & -1.9871+1.2410 \mathrm{sec} \\
& (-3.09)^{* * *}(6.38)^{* * *}\end{aligned}$ & $\begin{aligned} \text { ter }= & 0.8563+0.5032 \mathrm{sec} \\
& (1.31) \quad(2.69)^{\star \star \star}\end{aligned}$ \\
\hline $\mathrm{RMSE}=0.6677 \chi^{2}=40.73$ & $\mathrm{RMSE}=0.5959 \chi^{2}=7.26$ \\
\hline $\begin{aligned} l= & 0.0040+0.4361 y \\
& (1.11) \quad(5.14)^{* * *}\end{aligned}$ & $\begin{aligned} l= & 0.0289-0.2995 y \\
& (3.60)^{\star * *}(-1.40)\end{aligned}$ \\
\hline $\mathrm{RMSE}=0.0107 \quad \chi^{2}=26.45$ & $\mathrm{RMSE}=0.0213 \chi^{2}=1.96$ \\
\hline Accounting identity $y=$ pro $+l$ & Accounting identity $y=$ pro $+l$ \\
\hline
\end{tabular}

Note: 1 ) values in brackets are t-statistics; 2$)^{*},{ }^{* *},{ }^{* * *}$ represent statistical significance at $10 \%, 5 \%, 1 \%$, respectively.

\section{APPENDIX V}

Estimation of the simultaneous-equations model; dependent variable $=$ resident patents

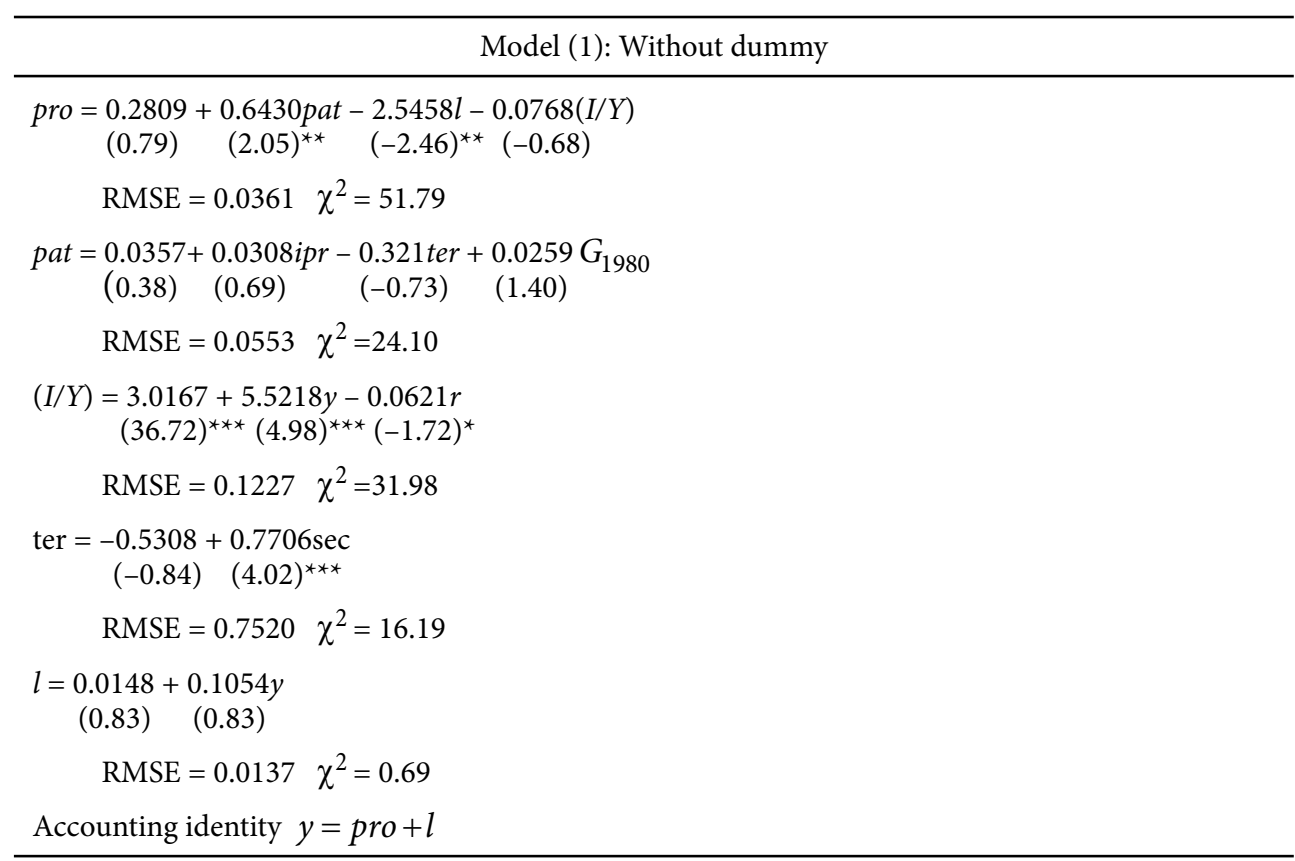




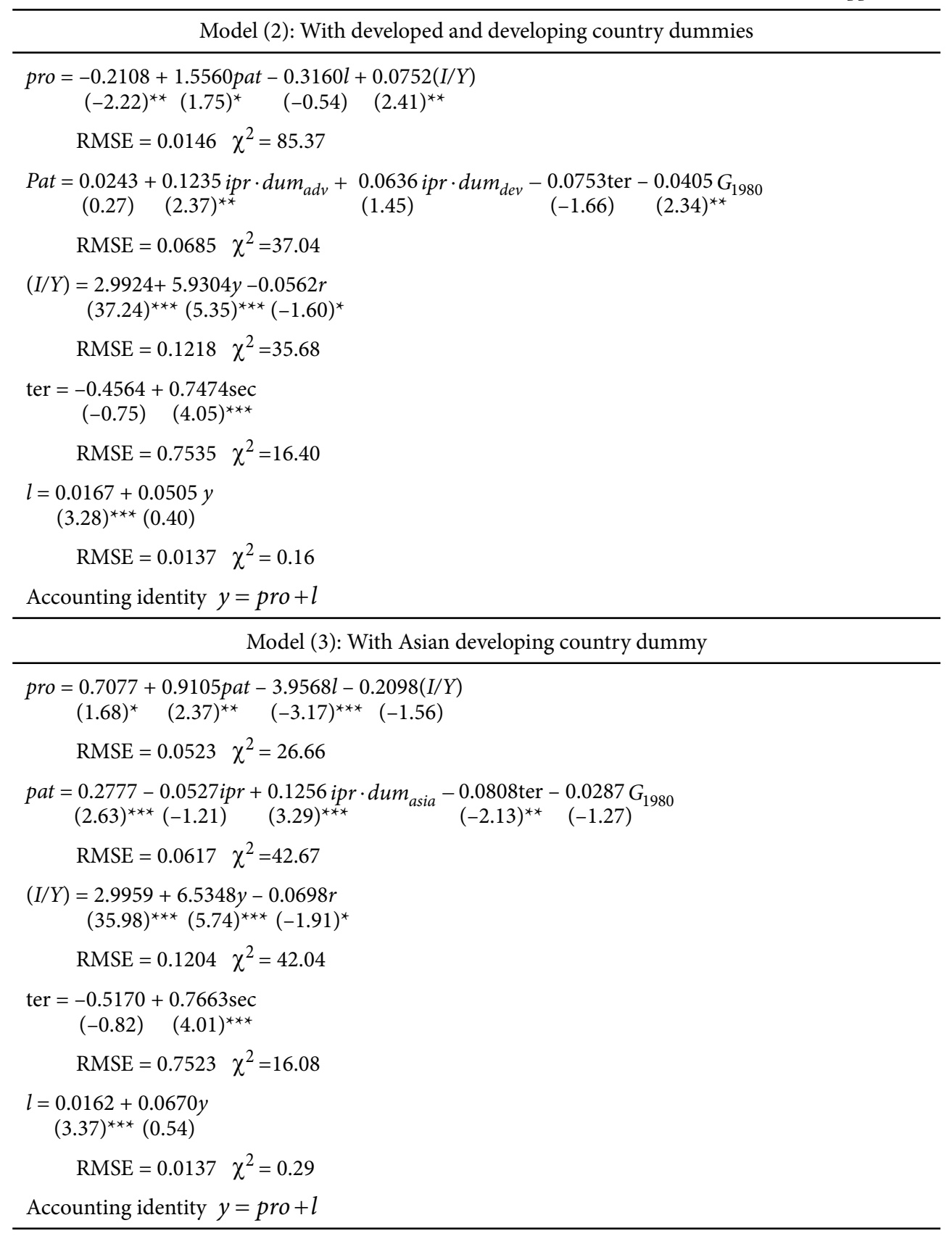


End of Appendix $V$

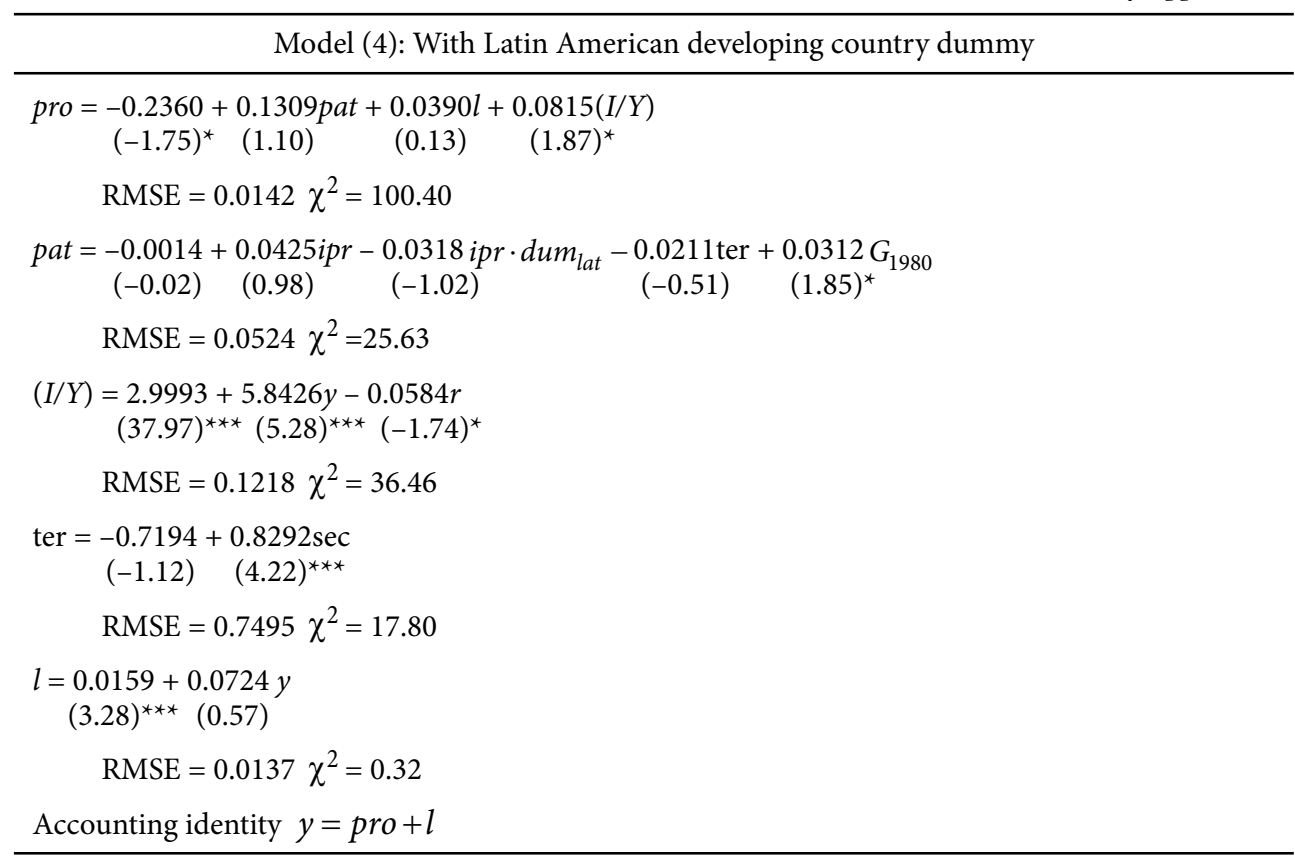

Notes: 1) Method of estimation: 3SLS (three-stage least square estimation method); 2) Values in brackets are $\mathrm{t}$-statistics; 3$)^{\star},{ }^{* \star}$ and ${ }^{* \star *}$ represent statistical significance at $10 \%, 5 \%, 1 \%$, respectively; 4 ) Exogenous variables are ipr, $G, y, r$, and sec.

\section{APPENDIX VI}

Estimation of the simultaneous-equations model; OECD countries

Model (1): R\&D expenditure

$$
\begin{aligned}
& \text { pro }=\begin{array}{c}
-0.1656+0.1078 p a t+1.0596 l+0.0070(I / Y) \\
(-0.23) \quad(2.47)^{* * *}(4.13)^{* * *}(0.30)
\end{array} \\
& \text { RMSE }=0.0087 \quad \chi^{2}=49.71 \\
& \text { pat }=\begin{aligned}
-0.2620+0.1818 i p r+0.0077 \mathrm{RD}+0.0819 G_{1980} \\
(-3.24)^{* * *}(2.99)^{* * *}(0.56) \quad(4.74)^{* * *}
\end{aligned} \\
& \text { RMSE }=0.0319 \quad \chi^{2}=23.29 \\
& (I / Y)=3.1810+3.4599 y-0.1264 r \\
& (23.81)^{* * *}(1.49) \quad(-1.81)^{*} \\
& \text { RMSE }=0.1244 \quad \chi^{2}=5.73 \\
& l=-0.0030+0.5644 y \\
& (0.83) \quad(4.95)^{* * *} \\
& \text { RMSE }=0.0060 \quad \chi^{2}=2.48 \\
& \text { Accounting identity } y=\text { pro }+l
\end{aligned}
$$


Hwan-Joo SEO. Doctor, Professor. Division of Business Administration. Hanyang University. He received his $\mathrm{PhD}$ in economics from E.H.E.S.S. (France, 1998). He published articles in leading academic journals such as Telecommunications Policy, Service Industries Journal, Economics of Innovation and New Technologies, and Information Technology for development. His research interests include management of IPRs, innovations in services and Régulation theory.

Han Sung KIM. Doctor, Assistant Professor at the Department of Economics, Ajou University. BA degree in Political Science, Korea University (1993). MA (2000) and PhD (2005) degrees in Economics, University of Washington. Research Fellow in Korea Institute for International Economic Policy (KIEP) (2005-2009) and Team Leader of FTA team at KIEP (2009-2011). Research interests include international trade, economic development, applied microeconomics.

Young Soo LEE. Doctor, Professor of Economics, Department of Business Administration, Korea Aerospace University. BA (1986), MA (1989) and PhD (1993) degrees in Economics, Korea University. Research visits to University of Washington, Economics (USA 2003-2004). Member, Review Board, Division of Social Science, National Research Foundation of Korea (2012-present). Adviser, Research and Analysis Supporting Committee, National Assembly Research Service, Korea (2012-present). His research intersts include financial economics, information and communication technology policy and research and development policy. 